の)

成 本

り 論一

立 0

与日

に的

求は

如近

よ 世

j北

亡 海

る

も経

の 済

で 社

あ 会

万
問

題

D

所

在

が力すおこお時女

、近がるるのけ期性本

和世要な。辺るにに研

人北求加境産北焦究

男海さでの地業海点は 性道れ鯡商が活道を近 ははたが人日動はあ世 こ人。そ団本の蝦乙北 の口その.が先变夷て海

戱增の代日進動地考道 れ加要替本地之之察に のが求商の域相い市お な顕に品需の関わるけ 加著従と要農しれこる ででわな動業て、ると経 私あざる向生い辺を済 娼るる。産る境目社 を。を北た制。少的会 機そ得海くの近らとを 能れな道み変世昌展 的はかにに動北本る望 - 鯡っはとに海先。守 組漁た鯡らつ道進考る 織にのがえれは地察な 的むが群てて漁域のか にら生来い動獲の対で 管が活した摇を経象 理っ苦た。守唯済之女 でたを。不る—活し性 き男抱関足。の動たが るとえ東商蝦生の年そ 公女たの品夷産注代の 娼の出干は地物目は社 へ戯稼魣肥物上を敦会 上れ人に料産す集保に 組でと対でのるめ年取

这

志

阮 ○織あア抗あ流他る間り キ化つイ方通地土加込 1した邓る。経方地らま ワて。でた関路とへ安れ |いアあめ東のはと政て ドっイるに以開甚変年い ..たヌ。鯡北発だ身間 場。民漁にを異すの状 所族に求行なる終況 請を従けなっ。わを

負社事るったそり

制会す䱒た地れま遊 る漁の域はで女

鯡し安獲はで先あと

崔

遊

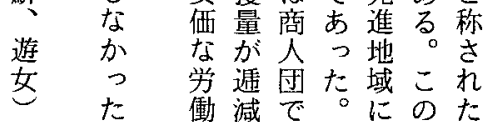

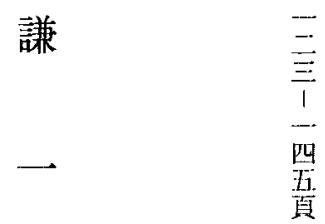


制口て 制 価変

幕度の心を䡃図図図

府に变る維 特が二元可二

は㧍動。持にみに应は

田け毛収古飢らよ近近

畑る被穫る饉れれ世世

永弱支能支のなば北杲

帒者配力配際い。近海本

買犠層定層相多目の人

の牲での早関少本人変

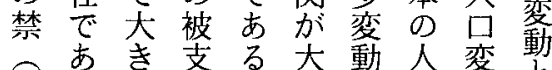

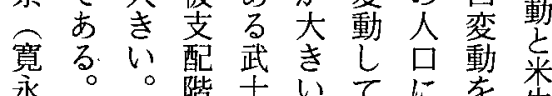

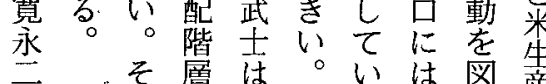

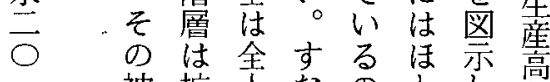

二：被搪人な方な

六 配再の ちち年よ゙も代

四、階生約、貢変の年

三 層 産割餙幑動で責

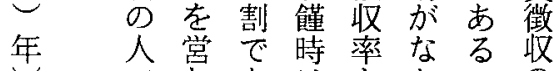

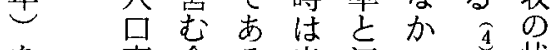

を変余る米江つ幽

法動地。価六た可況

令 のがそがにこ市

化 太な の

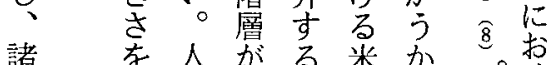

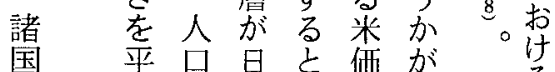

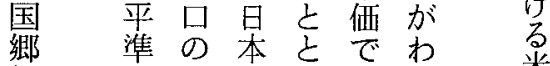

村化九の蛮あれ

江さ割米にるるる

被せは生年。

仰た被産貢年ま

出社支高徴貢た

会配 の收徵

慶機層均方率生

安 能を゙三低の産

の 㤎あ割卡変高

御、る以古動に

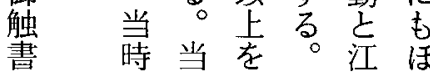

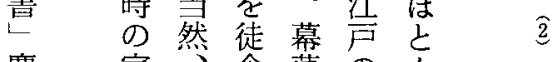

慶家族人食藩 の

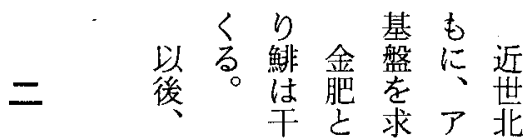

近北鮈呼めイ海

世海要ばて 道

道駆れい民㞎は

開遂たた族蝦

拓 ᄂ干松吕夷

の て 䱦 前 先地

歴いの藩 住と

史く代地方呼

は。替がるば

彼こ商、辺机

女系以境

た過亡後の 米

ち 程し、地作

をにて本とを

除合鯡州さ中

外理漁商れ心

L 的獲人比

てなにのい方

は雇商商たる

考用業業。農

元契資資当耕

ら約本本初社

れかが投、会

なら投卡和 の

$<$ 疎卡の人中

な 外さ対之で

$\supset$ さ象学非

てれた地イ農

いた。へ邓地

非無と民域

生尽変族 之

産蔵貌 の

的な交て

な鯡る易極

女 $の$ 之

性群六て

之来方特

し亡異 異

て安㞎な

遊 価族 存

女な間在

が 学 取 で

出働引あ

現力にる

乙 $\begin{array}{lll}\text { L } & \text { 存 } & \text { L } \\ \text { 続 } & \end{array}$ 
図 1 近世日本の人口变動と米生産高 および年貢徵収率と江戸米価

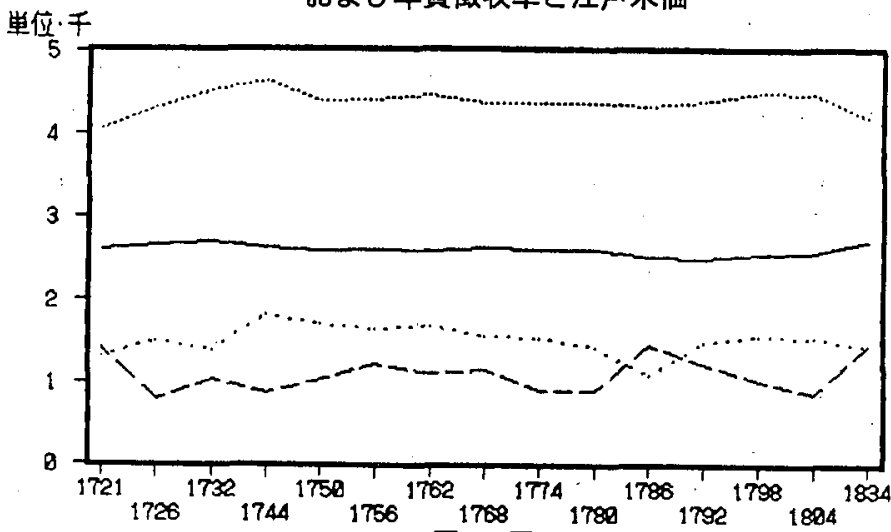

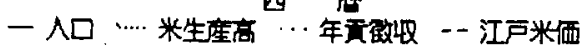

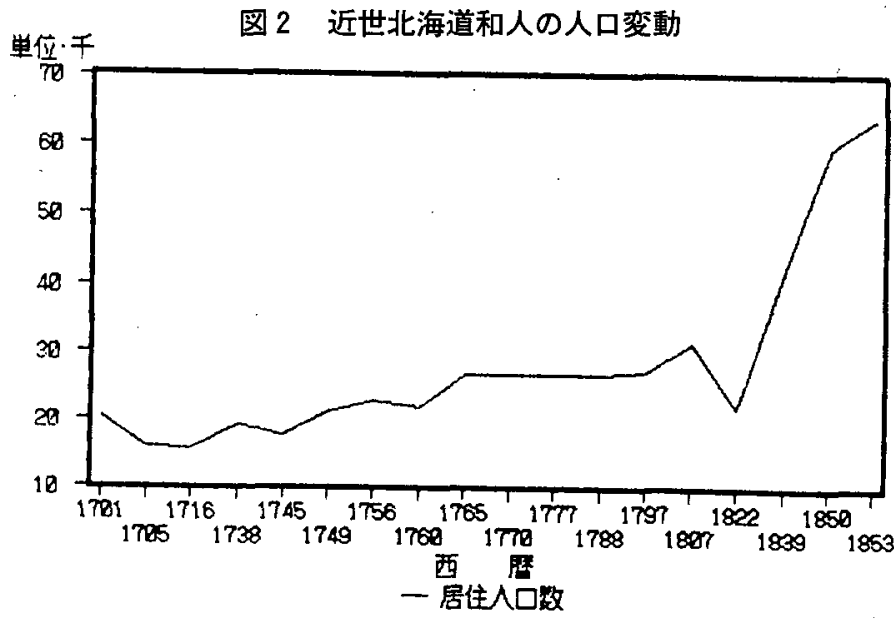




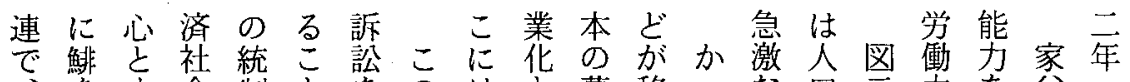

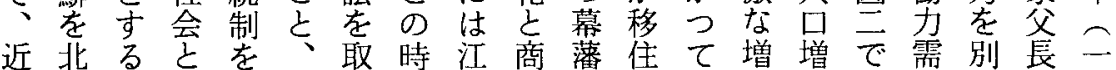

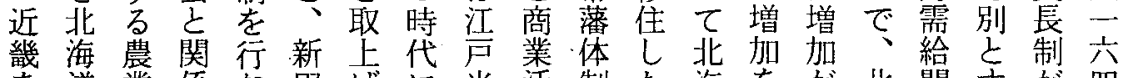
を道業係な田げに米活制た海をが北関すが四 中の生がをなは価動の边道経北海係机つ九 心中産深こ開い幕ののな境は駼海道を代よ

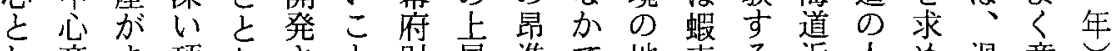
し商ま項なさ之財暑進で地夷る近人め過意 た品っ自丸゙せ、政傾が商で地こ世艺て剩識に 綿とたはでる商は向漸業あをとあ㤔なさて のしく通あこ業破と次資っ呼に社二領労机必

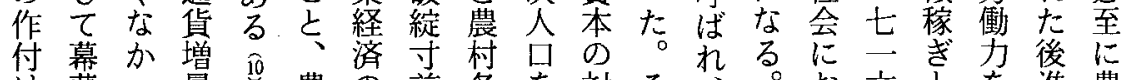

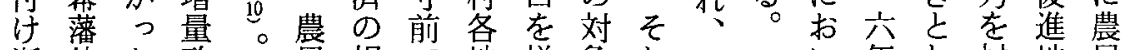
漸体た政。唇規で地增象しそい年し村地民

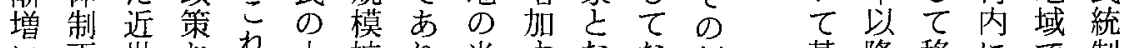
に下世的小拡り米方なな創基降移にで制 対の北上は商大幕凶るっに笪調漸動滞あを 卞本海び喜品に藩作原てょ期䞶次し留る強 る州道農宗生伴体因いり劸增てさ東化

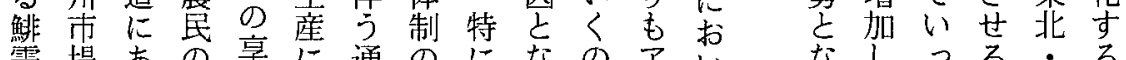

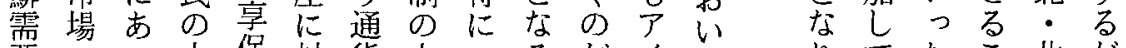

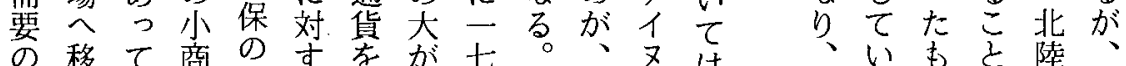

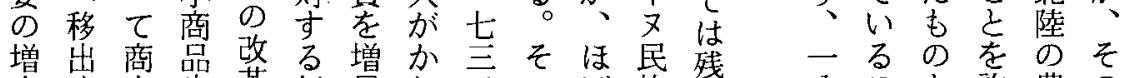

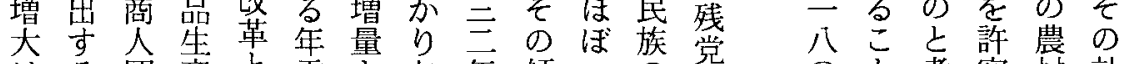
はる団産真さな年倾 当气にに呼街せ手の向七生流七がえでて果

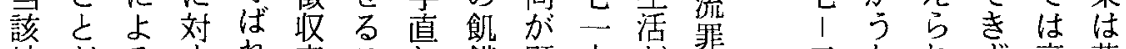

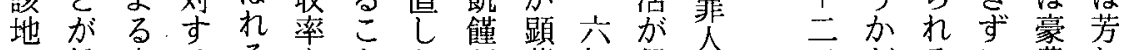

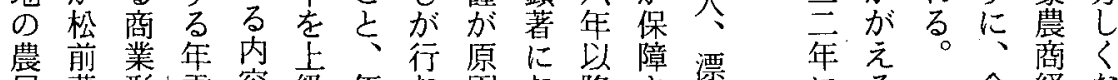

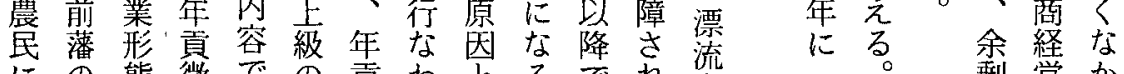
にの態街での貢わとるでれ著一。剩営か 対存心收古米增犯毛のあた者時特労なっ

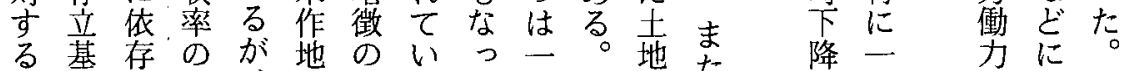

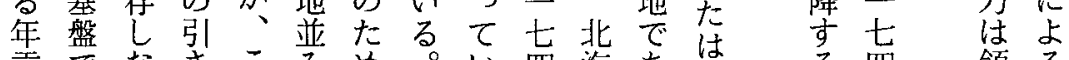
貢でなきこみめい四海古戦る四領る

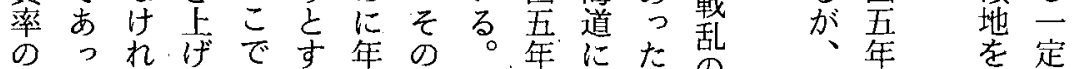

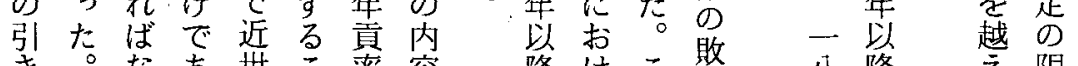

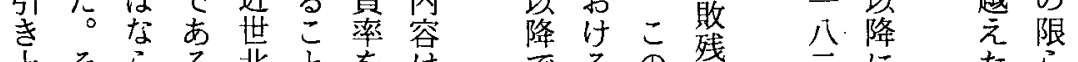

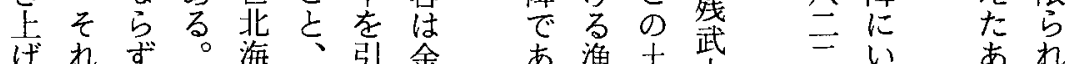
げれず。海、引金市漁圭二い表机

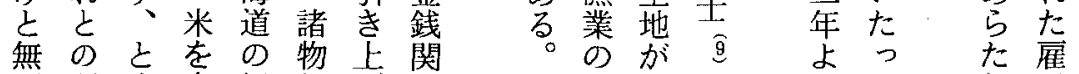

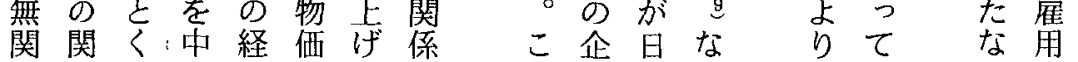


て頭臣降あ が前わよち

定百に近激つ木ほ木進つつつつ十

える係

着で知世北くて

18 蝦たでたは嘎転や紀こ起生中

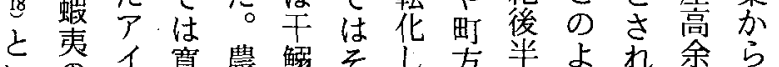

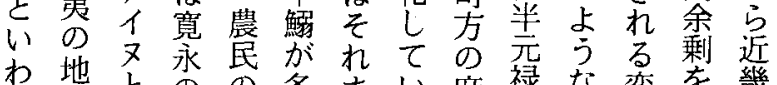

扎内との地多まい庶禄な変を盏

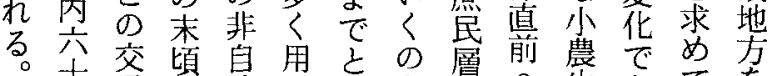

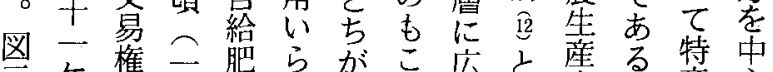

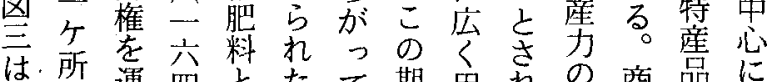

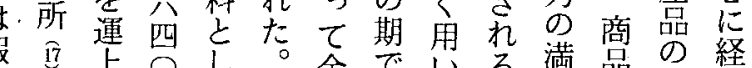

策焉上 0 L。金でいる満品の経

地が金、てし剪あら面生製済

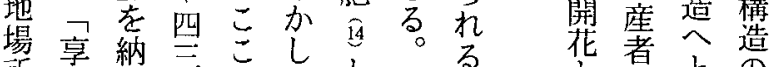

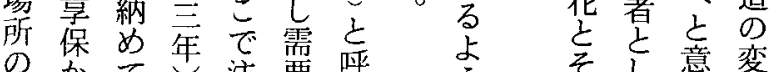

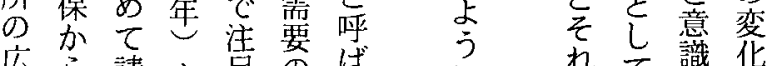

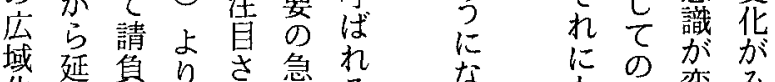

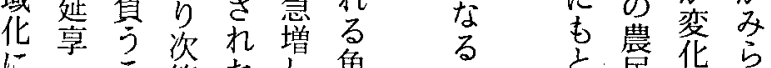

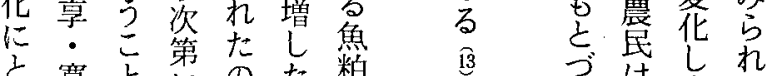

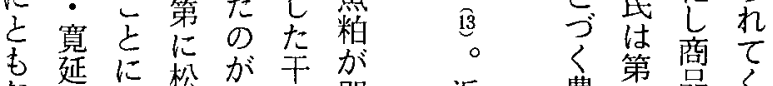

なによ前鯡䱦即近農第嵒々

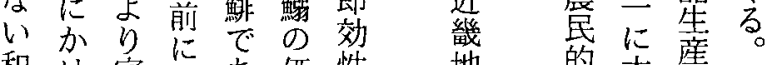

和け家出古価性地的李虚農

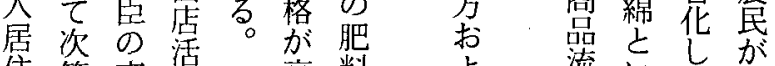

第交躍高料占流いう芷

地に怼躍 騰亡

次の代め年杲開品品京

搪体行近尘い曹通通食

大制吉江泉ら農、農艺網糧

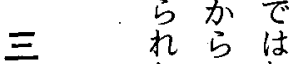

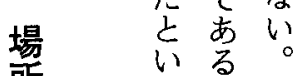

所 青光金

筫算气萉

制

にL

近

世需

北要

海さ

道机

のた

経 鯡

済は

活 本

動

茫太

商 平

人 洋

団沿

の 岸

仲 の

介 干

に 䮷

\&

つ価

乙 格

日 競

本 争

のを

経 行

済な

活

動 飞

人れ

参索

入遂

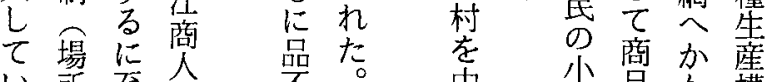

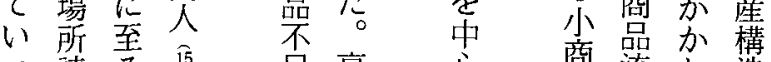

$\tau \frac{L}{\tau}$

っ請る占足享雀流わ造

た負のが架保文唯通わの

いい

こ制が松敦期的網る維

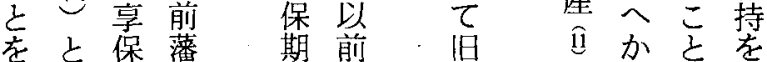

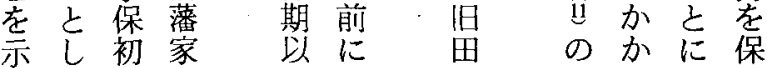

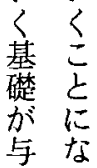




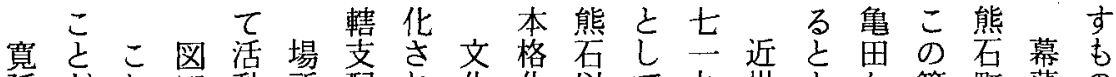
延加れ四動所配れ化化以九範町藩の 末分にはを請、の、・さ北の北もら囲附体で こるよ近行負も文文れ基年海に東を近制あ 二。れ江な制之政政て追盤ま道息和ま市る

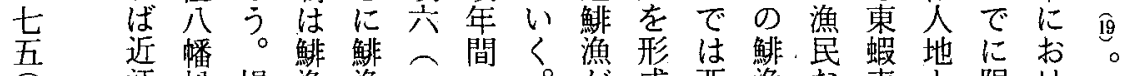
$\bigcirc$ 江 松.場漁漁 年 商 前所業業八二 許す在はど地し定る

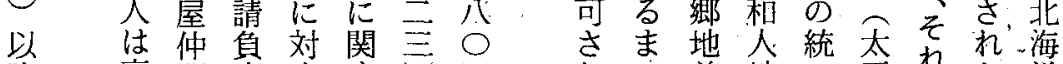

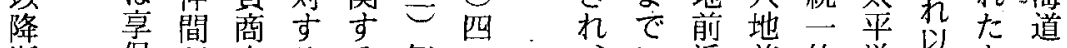
漸保が人るる年। 次年積の商—に一享は漁浜な沿を北こ和 積間み目人切松八保至業に支岸を螝乃人

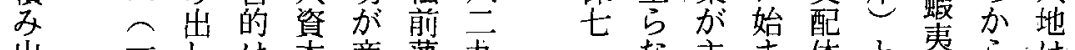
出二しは本商藩九主主ま体と地らは

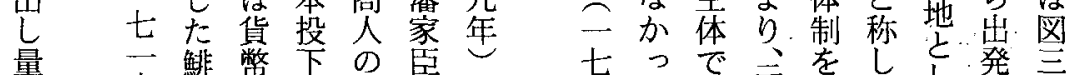

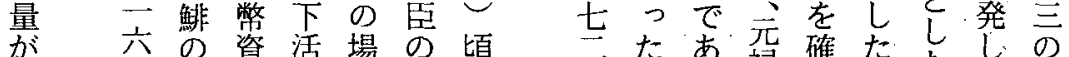
低、广数本動所 場 に 下 七量 の学請乺大

乙 七堌本負知網 て 言恳殖質制行漁

い五示で上へが法

く 年しあ方と一方

が、につるるか切導

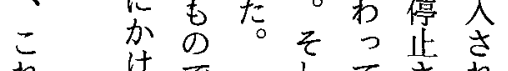

れ 的で してされ

は大あてれる

北量る 商く。知よ

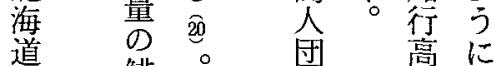

に解。首は高にな

お、䒚投米る

け 近 资 金

る鯡方地 資 本 琾

$\begin{array}{lll}\text { 漁 } & \text { 万 } & \text { 物 経 } \\ \text { 櫵 } & \text { 堌 支 }\end{array}$

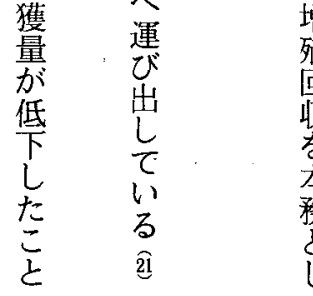

殖給

回 亡 完

収をな 全

本領商

務主 業

之一瓷

三たあ元確た。た して

こして四立松熊い㧤

年少蝦二世前石るり

に魚六て 藩以

は魚地九心は北す松

熊肥鯡二つ熊をな 前

石乞漁した石西わ去

関ては年。尖蝦ち中

内解僅に亀夷ほ心

よ解吕は田地注と

り需に熊に焦し

以要武石番旦前て

北要士ま所本半東

へれのでを海島は

の狂商の置沿と現

追た場追岸呼在

鯡高知鯡和お代の

が京行等人机画

認楅の許とびる館

め四経可予才地市

ら二営さ イホ域龟

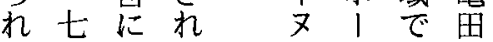

て置る。

蝦九吕。交ク方海。西

地年漁保、易海。西

鯡以業四、監岸前現

漁降経乞視、藩在 
図 3 和人の北上

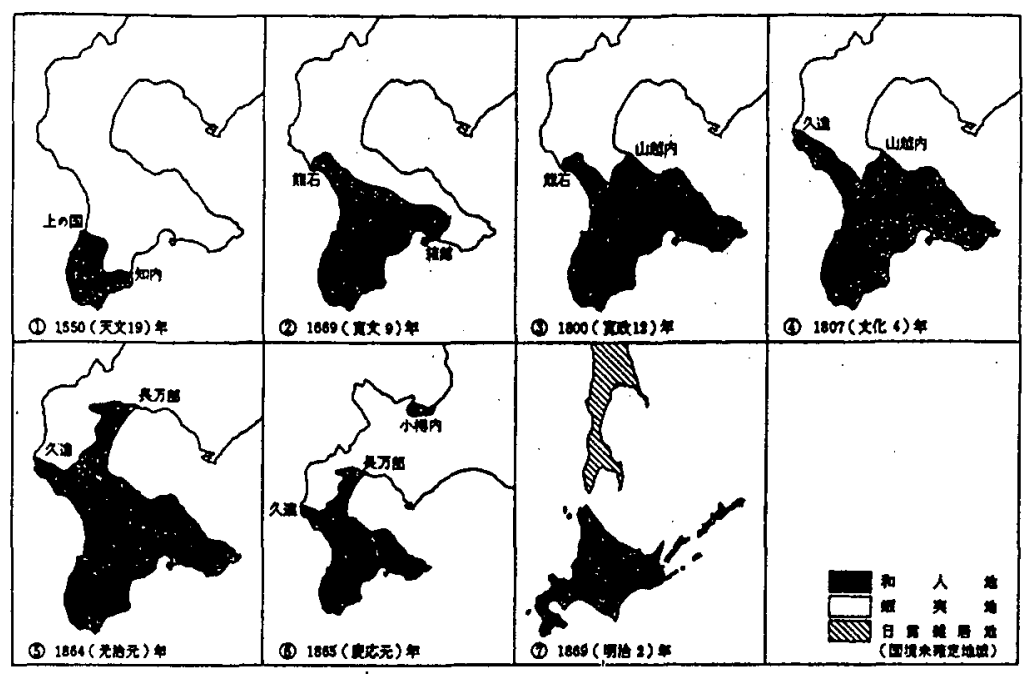

図 4 近江八幡松前屋仲間積出荷高

巣位:

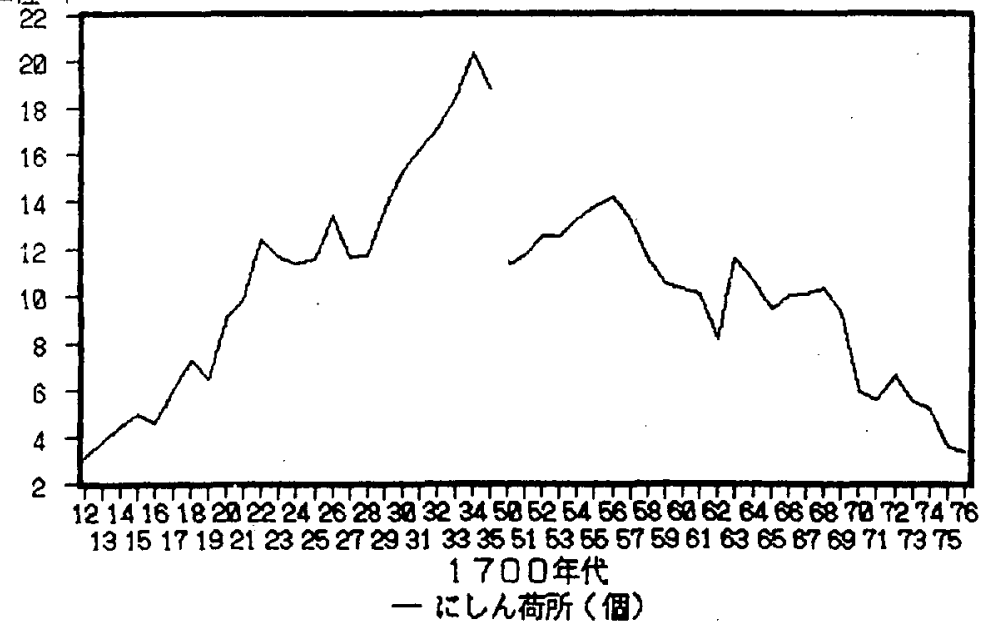




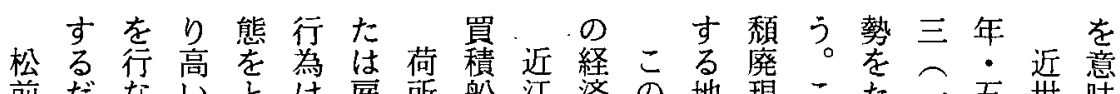
前だなるは雇所船江済の地現こた二五世味 地けい利りゆ船船と商, 活頃元象の にでな潤つるでとい人動に問とこう五な海る お、がをつさ本はう団がな屋松とて言い道も けなら獲、机店松商の活る商前はきこしのの るく船.得廻ての前業流動と人藩近た年七鯡で 北商旅しし船は指に形通し江。の: に江近に年漁は 前品を过々い示進: 態形始差.成密商江鯡のはな 船をつうのなに出を態めは長着人商役全、い

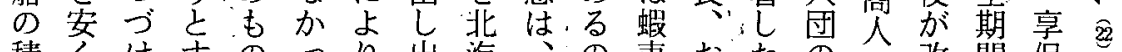

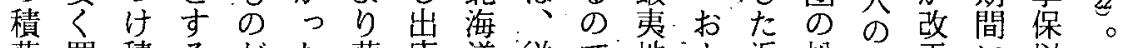
荷.買積るがた荷虚道従で地占近松取正に以

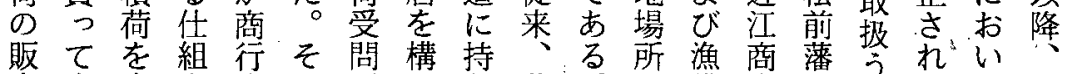

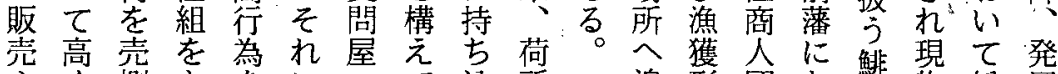

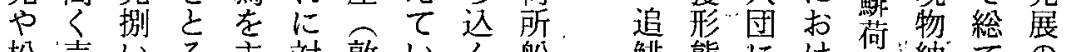

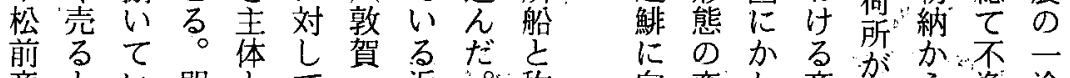

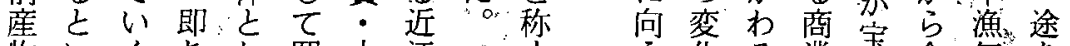

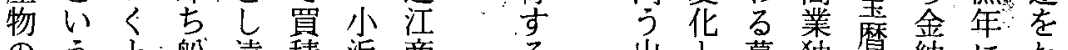

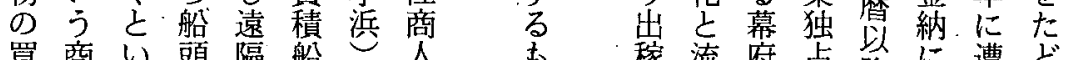

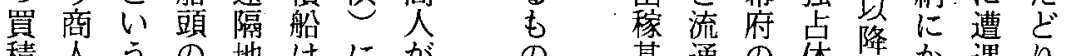
積人うの地はに古少基通の烋降か遇り

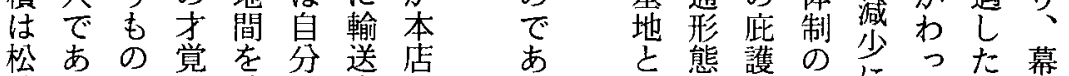

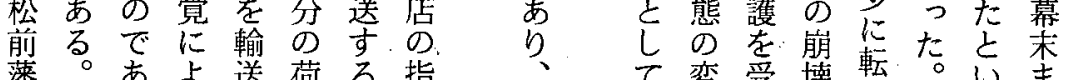

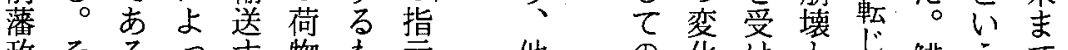

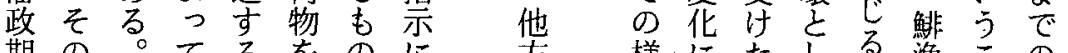

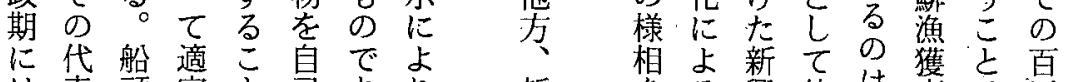

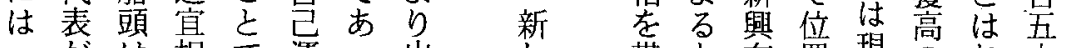
フがは相で㷑っ出し带も有㯰現のな十 沖北た場、送て店く列の力物堌く年 之前にのそ兽䓒が台てで商けで徵概間 口船ん高のる船集頭く古ら徴さ技を

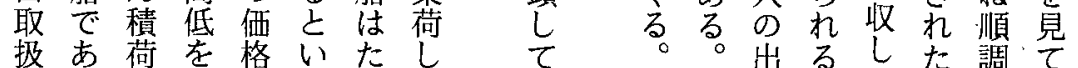
扱あ荷を格いたして 。出るした調てて

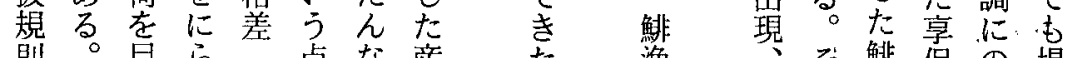

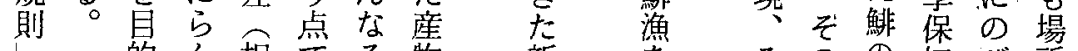
的ん相でる物新省をのの初び所

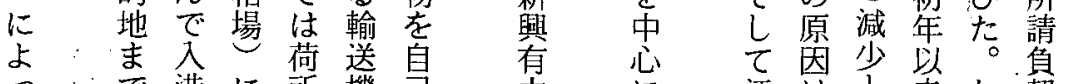
つ:で港に所機芑吕に江は策し契

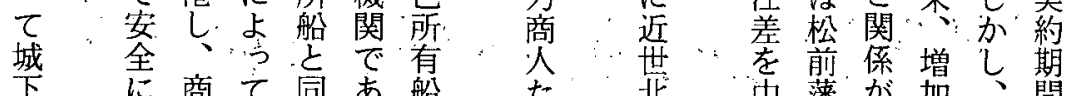

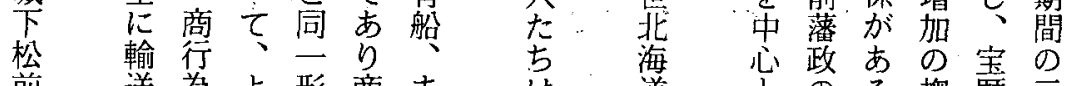

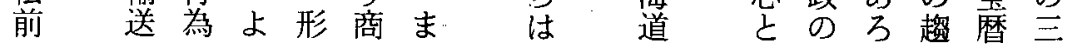


るのの獲確他品

諸堌手得保方段当当

のをに商第近々蝦

前自よ業一江交夷

貸的り利の商換地

制之産 益目人しに

をし物の的はて拉

亡て 類 拡上こいけ

るアを大机たる

亡 又収奪図商 の 松業

にににつ人圱怔は

よ漁近た団物審主

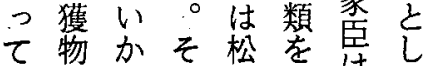

否のたと俩本岁て

簡ちて 藩州 $ア ア$

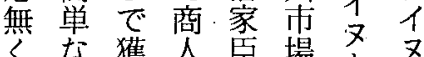

産加得団等 場 亡

物工しは古運章行

類法た漸らん易な

をを。次知でた。

増教ま交行壳産て

加えた易場却産お

せ生こ利所 し 物整の

る用にの交潤近そ

を具あ増易を近の

えのき大権獲商漁

な改ずをを得售獲

以良、図運方存物

条をさる上る仲を

件指らた金の仝松

を示なめとを等

作しるにい自し藩

$b$ た利交 う的し家

出追率負し生等

た換求 の料て活が

。手のごをい必乃

岕段た ま执た䎡

ににしししな゙た

ま1アや之か立希

あヌ古威にし、交望

き㳔産な在よ利換 る

ら市物 よ゙て 益し諸
そ置いららるる。

転け建大こイの筼在

化ら網場れ・頃禁江

しれと所らイにさ差

て、いはのシなれ

いそわほ各力るて東

くのれぼ場りとい在

生る奥 所

物組所新 $シ$ 量 城

ををと興ホに市

和使称有 ‘よ松港

人用す力

製しる商宁各に限

品ま遠人や場はら

とた隔が!所松れ

交了地䙾 シ の前て

易1で延ヤ評藩お

す邓あ以り価のり

るをり降! が庇

主労松乔工確護こ

体働前前卜定を高

で者藩期 モ 始受声

$\supset$ し管こ: 如たは

たて理七路近松

も使が四 ブ。江前

か役手八ツ薄商 三

、るに八; 所が

こ占な八戊支称

のうる年尔い后し

よなとま文的開

りるまだアるるま港

新。あにツよえさ

興当つ請ケうえれ

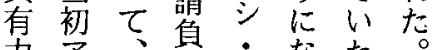

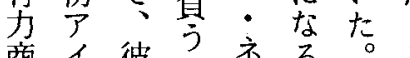

商1彼已六る。

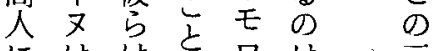

にはは橉当なな

属痤時なる゙当。巷

寸者禁学の不外

ると此 地当地

労しさ。域! の

働て れこで

者位てれ市入 


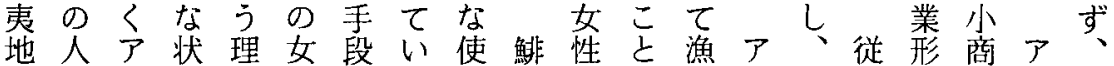
に口イ態由性とる役漁はを労イま来態品イ商 おは又はに航さ。は獲緋繰に又たかが生又人 け極が幕よ行れア新高をりあは運ら北産の団 る端和藩る禁たイ興の潰返た労上場海の漁は アに人体。止のヌ有増守しっ㗢屋所道增業漁 イ減に制ほのでは力量こてた力の請に加労獲 又少使末法あ労商がとい。支会導と衝量 のし役期十説る衝人要なたそし所人入干者確 人てさに八が。者た求どのしてとたさ䱦化保 口い松世柀をちさにでて雇しち㧈のはの はくた浦紀たらしがれ使あ漁用てはた代宝た ほ。当武中くはて請る役る期さ番場時替糜め ほ時初四葉な狡苛負よさ学㤎机屋所期商年に 半代加郎以に猾酷っう働終るをに亡品間自 減はらに降守なたにた偠わが設運歩とた しや見よにら乱使仲な2 6 孝つ、置上調し二漁 てやらっはれ暴役場る。とた彼し屋をて七業 し下れて 蝦てなに所と等たを同㥸五を

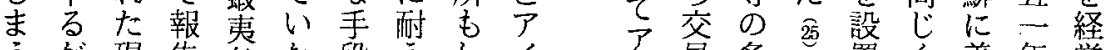

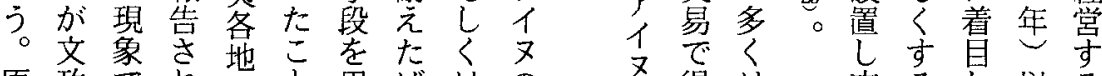
原政で机で之用ばはの 因年あたこ毛いか奥酷 は間 ろ $\widehat{2}$ の あて.り場使 番加要占つアで所毛 人ら。がうてイななな や安出、な、ヌくどお 出政稼必性この、のさ 稼年人焉的れ女乃松引 人間にし虔ら性イ前悲 たっ酷委街のたヌ藩惨 方使こ待地ちののさ が八さ報行域を女監を 蝦一れ告なに妻性視加 夷八性のわ和妾たのえ 地、的時机人化 5 行て

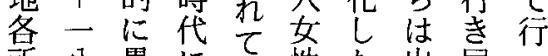
所八愚にい性た出届っ

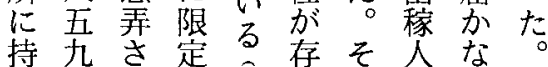
这年れ包在れのいア ん。しは性地人 だに結るアな神的域又 各か果も1か威欲での 種け为のヌつ岬望行悲 伝てアでのた以のな惨 染西人は悲と北解わ菩 病蝦又な惨い人消机酷

\author{
苼
}

は得は

男た狩

性物 猟

は品に

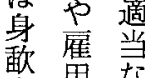

を䡒焦な

繫写地

い得域

で物住

燥嵒居

持

まっ 漁

た $て$ 期

種 生

々 活近

な地亏

雑にく

業引と

に揚 海

使げ边

役るに

さ移

れい動
支るし以る

配 社た降に

人。近顕 至

を

置

になる

代。で

るこア

新れ

興はヌ

有西は

力白労

商 本 働

人各者

の地に

登で転

場 $の$ 化

苯綿乙

北生

前産く

船をの

と主で

い亡あ

商る る 
らに多なるりたにす営場具八漁くの獵族菌

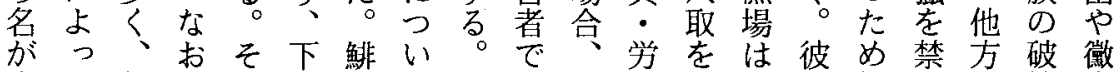

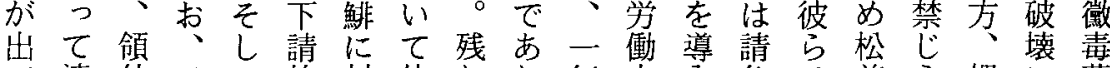
$\tau$ 清外二て的対仕りり年力入負は前ら蝦に菌 い算で八天漁す込の、限・し人二藩れ夷あな るさは取明業る親八場りそて直八のて地るど 招津に期経需方割所のの間轄取許い請 密の を、軽雇へ嫦要なの請も他接使と可た負病 受漁: 角二著吕し鯡負の鯡的用呼を彼場受原 獾南さ七に堌では人で漁な人ば得号所。菌 る高部机八対大着江下な業経をれてでに 仕が・る一吕し業差請くに営指る追あ松 来大秋出 1 る、で経永必を導 解つ前 りき田稼一仕そき運営い要行者。之た地

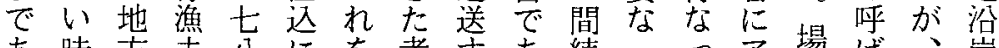

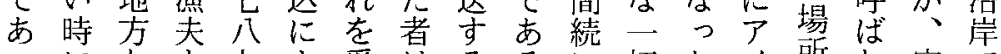

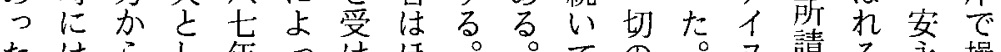

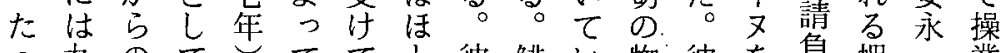

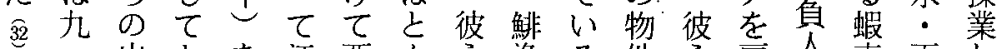

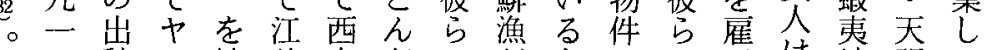

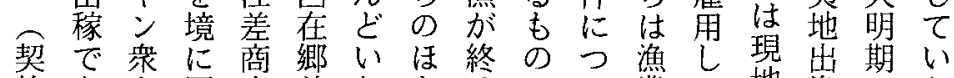

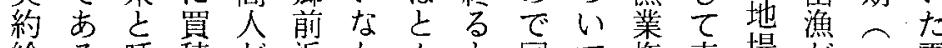

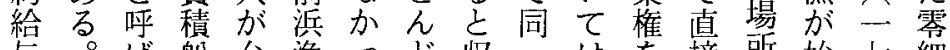

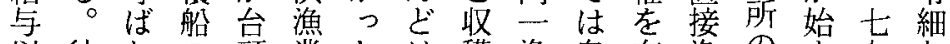

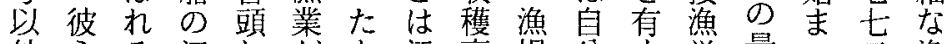

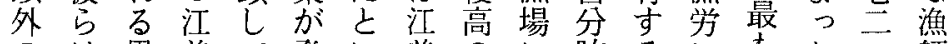

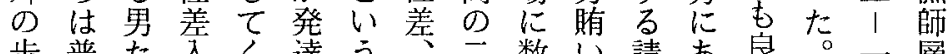

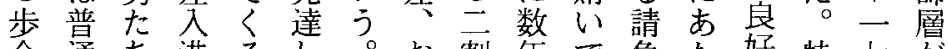

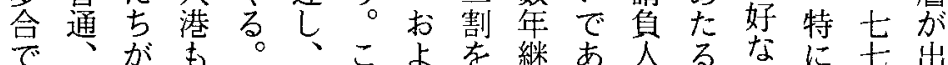

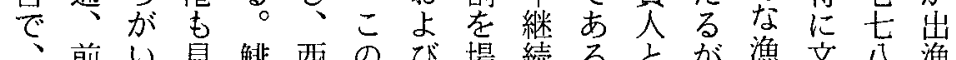

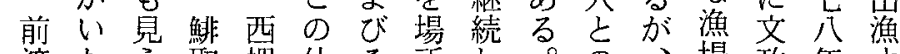

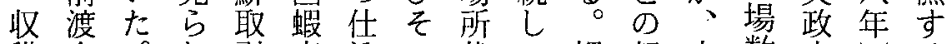

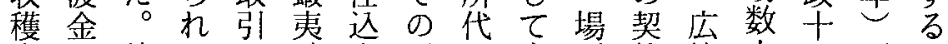

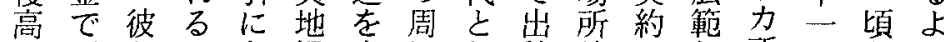

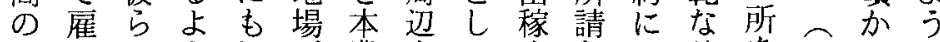

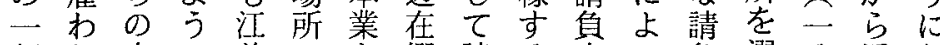

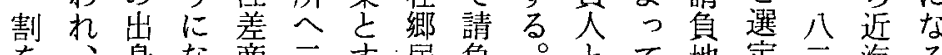

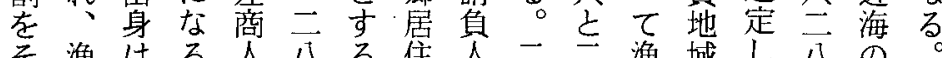

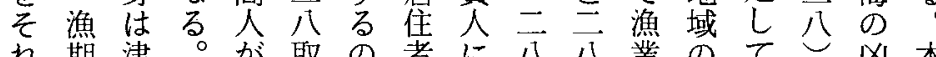
れ期津。加取の者に八公業のて四本

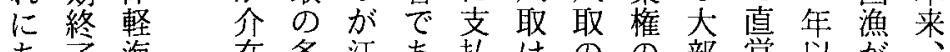

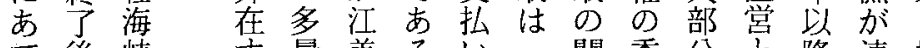

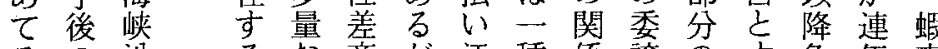

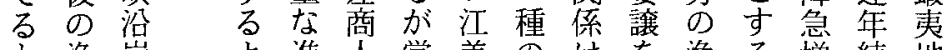

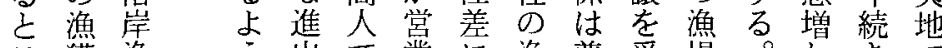

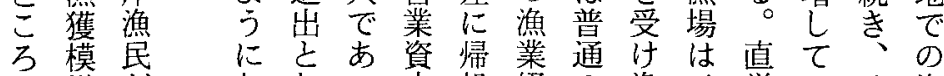
吕様吕なな子本忛経の漁営いそ漁

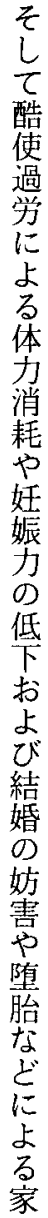<smiles>[SiH3]</smiles> 
紹とさ政立女女花れでうの

介近㣗策前海ら彺る は世遊るに後保のいがここす在る 花北所形々等洋存う位亡のる染地 街海しでり湊子在こ置に一。市域 を道の茶这に氐感亡专上定徐る 社 構の吉屋ま自はのにるう海。会 成花原渡机然近大なこて画にそ会 寺街風世る発世きると支を彼し花 るへの形生北さ。に配中女て街 業松の公で的海ま遊な層心地考 業前一許、に道た女るるはと域形

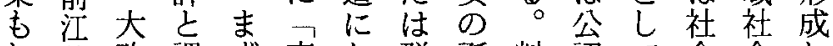
し差改課ず売お群誕料認て会会し く革税東女け集生亭と各にで、 は松を吕蝦しるしは・い種囲彼い 前行実夷の遊て彼置うのい女く 嶪箱な施地創所 が館つさ二出のるらら続業まの合 整館た㣗带を発状が待きが㧈存に 備が時るの管全期時根た況定合を盛て在 理仝々期樾時言関地至るにくがず さ珤地期段係域撲のな。大当 れ紹る第箱階しにがでる地き該 て 等第にて単花 活さ尔段に館区いに街るそ社な地 況机階子段分る散の行会るに る柱遊階しと在基こて会に遊 呈の箱所はてい守本の当支つ婈 しは館幕いえる的公該配れが て天㤎が府るよのな認区尿て散 い保開成の方箠さ画は当在 る十港立蝦第。は成机のこ該し 状—場し夷一な要た機の社て 態—松地段々素区能用会い を二な前直階、婳的いはる

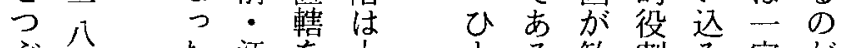
ぶ四た江を十古歓割み定が さ四こ差契八引。楽分をの常 にとに機世得こ街担当区で 上年よおに紀社こでと初画あ らでりい年でそ組はをる えあ異て幕場的稼の織默彼。 たる 人者府所認業中的認女い 結る揚その請識のに整するわ

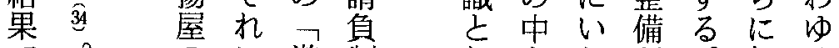
で。のに遊制し心わが。与る あこ設刺所のてはゆな次え私 万の定激成彼遊るさい占娼

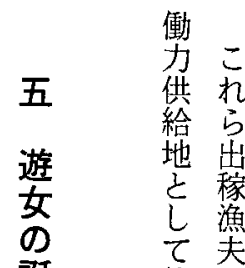

誕位の

生置 存

づ 在

けは

六

く 取

亡

にに

な 請

り負

近

世場

北所

海 経

道営

の が

人松

口 前

変 地

動 の

の 2

大な

き ら

なず

要南

部

な 津

$\tau$ 軽

(

人秋

も

の 地

で域

あな

る 


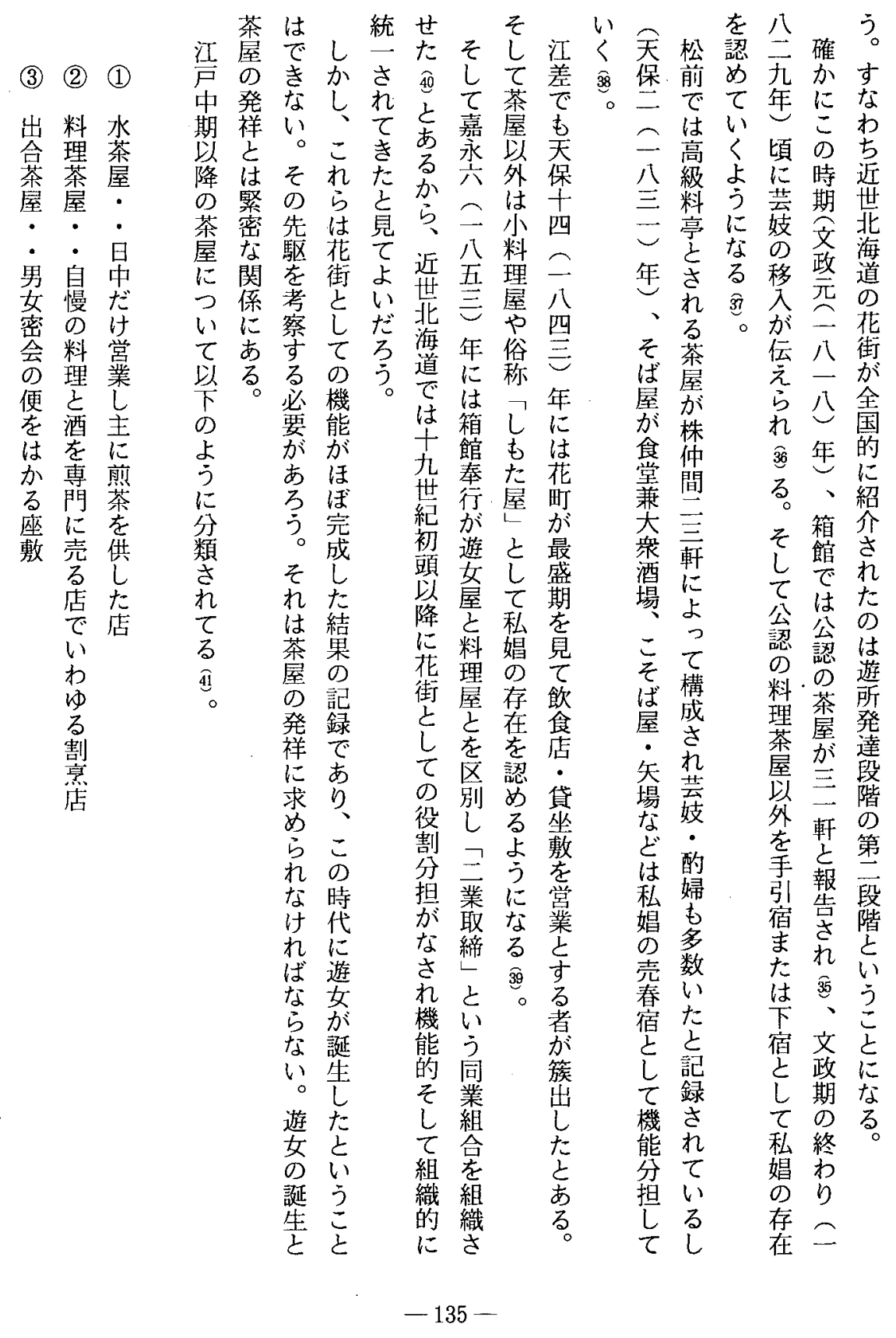




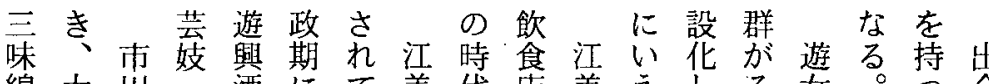

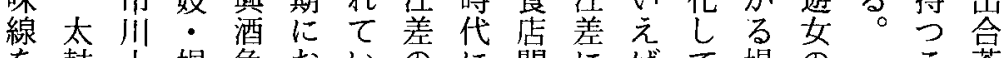
を鼓十娼色おい宁開にば場の茶

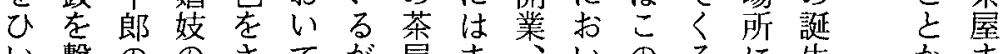
い撃ののさてが屋ま令のるに生かま てな整区せは、にだ影て構と付は浐た 謡々゙理別る料こつ群の茶図集随水後は ををにはを理れい集町屋が客し茶

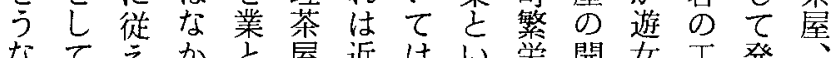

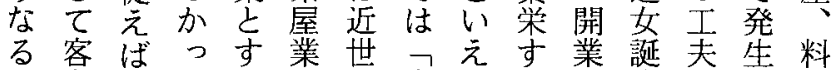

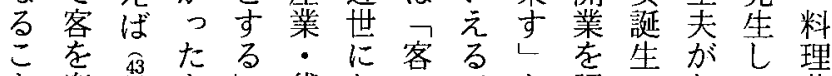

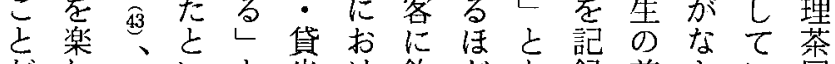
がしいと坐け飲亡゙あ録前さい屋 始ま安うし㢣る食のるし提机る。 ませ永のて業茶遊气て条て。発 り、期が二に屋遊㚣とい件くは祥

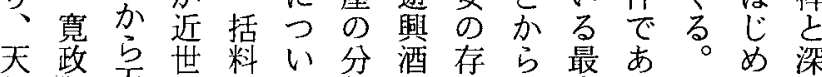
保期㭐菲理て類急在料古るこの のの明海茶はををは理の盾のうか 八終期道屋、混さ見䒩も。工方名

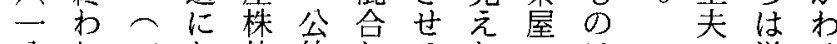
八り二お仲的しるな蚊る

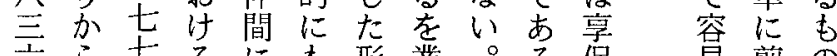
亲ら吉るにも形業。る保易煎の

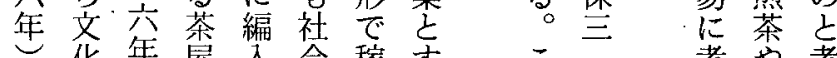

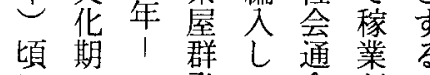

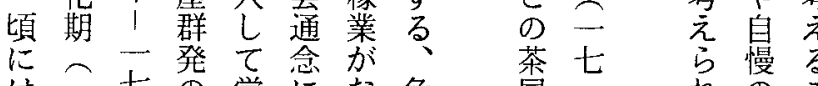

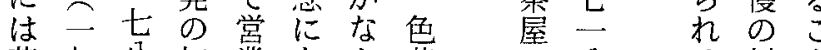

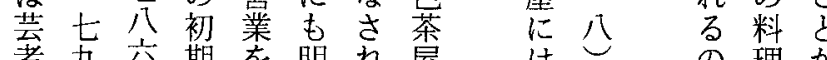

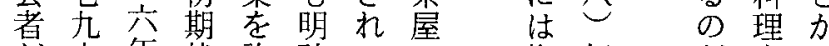

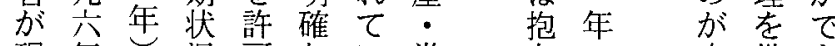
現年浣可ない遊努で少供き れ十湎でした廟

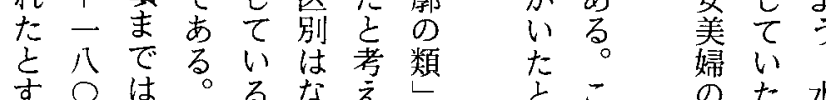

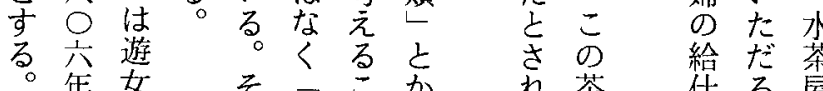

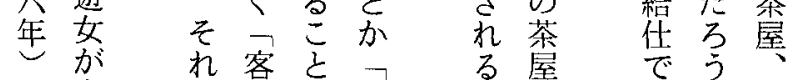

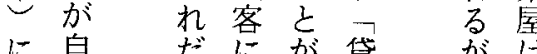

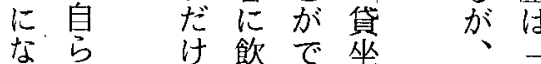

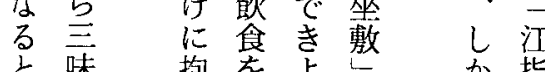

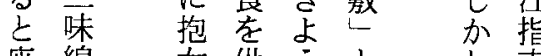

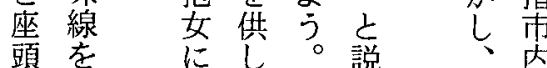

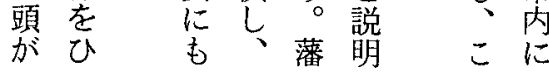
に揚 は屋 貸代 坐用 敷 の 余遊 呼屋充 ばなる れど呼 る既先 こに遊 に遊忐 な女座 るの 敷 稼 存 業 在 の 前 前 身 提 でさ 発れ 祥 社 乙 会 てに は公 水認 茶さ 屋机 あた でちが料料し こ莠茶の 。机屋屋意 一らは味 般が人後合 


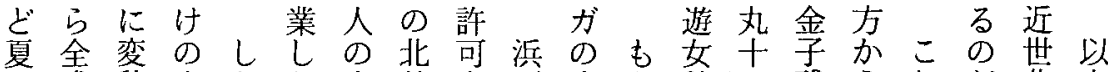
の盛貌内市出前を分字う稼二残ら㧈が北上

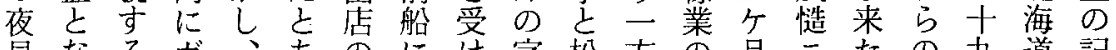
見なる力゙、あのにけ字松方の月三たの九道記 せり。, 鯡る総乗てと前機御受旅茶世の録 に江こズ漁众称組小は・近能奉取人屋紀遊を 異差の幾が。でん屋群箱世分公作初女総 な前小人活 あで掛集館北離三貴あ抱頭の合 る浜屋と況つ来けしの海は差殿つえと誕卞

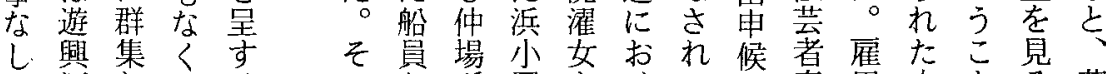
し 酒し亚る

余色た び 亡 巷 が㕣 世 わ兵 三紀 わ化忩昧末 れしの線期 る、字等以 ほ後上引降 ごに垀引!に 活はば松な 況昼る節之 を夜私を従 呈炎娼方来 すなたたの る 方京相

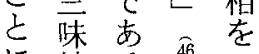
に線る季正 な線変 る太浜 い守 鼓小うる 彼に屋よ占 女てはうう た䞅文にに 方方化遊な は事四興る 飭本二酒。 棪帮一色潁 公江 $\bigcirc$ 業邊 契声七方に と両年る 小 乙国项小屋 てな左髦 のた所屋とけて奉用少之る茶 党ちまで呼るい危公は㚣にこ屋 業へた稼ば遊な峌公史美なと女 期菓は業れ女い美料婦万がの 間子奥したの。古出にたうで社 は・場た私誕彼るしょち。き会 四餅所私娼生女占候れは的 月類か娼た亡たう代言う存 冺らたちいちにま年在 ら小の古でうの名た当も方 七間鯡であ観身名は亥しし大

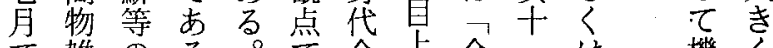
で雑のる。で金上金一㟔機く 港類送浜過 でをに尔ヶ者両りの福て の売従屋き年や也寅年たい 往り事亡な間秦十季は。 来、吉は心平公私一秦組た がまる江の均亡娘月公織の 終た兰差はほし御迄人、的は 了公前私はて貴丸热に十 す飲取浜娼十の殿至し整八 る食や鯡向四契方皂て 備世 秋・出漁存・約入年抱さ紀 口酒稼が在五で来元れ氺 に類ヤ終で両あ辰身らて 期

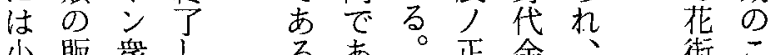
小販衆しる市。正金、街こ 屋売、た方し月吾そ心立 ををま後を。吕よ拾の 形で 取行た机し b両多態

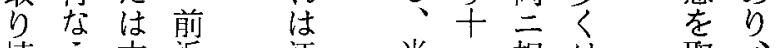
壊亏本浜江当二相は取: し小州の 差 時月定津可こ 休前加使浜迄只軽始こ 
の

業 但 等

務 しい者は

遂、たに地

行 右し 御他

に渡、座船

配世又候 に

取 の

亡゙ 住 符 売

称 のに物意

亦義ては心

るは為决廻

洗、乗 て 船

灌多通取當

女 分扱㵎

が 海且不出

必岸水相父

要に主成 滞

上 罷共仕船

さ在占来中

れ候りに

た者酒御 船

こ 御料候 永

ら 候 等 猶 の

の。被又者

抱 年相 水 共

女 頼主積

た候共令

5 得入荷

は は替仕

業立舞

務 是 酌 の

遂文取 節

行賄女被

上致被夫

同来相々

時り頼内

に候候用

売 義 得向

春 には相

老御交辯

強座口遣

要
て宿 る肉の五 ○稼代る例 い泊松他こ箃上八।人金季え る。前方れのにでが間ば 洗藩、ら飽打年八あ二雇一 濩に洗の満込に四りヶ用金 かは灌私をみは至雇年で至 ら沖女娼ひしゼ年用間あ拾 身のにたさ筫二し期にる苯 の口つちく港バの間換 廻業いが壳張コ大が算. 据。飯 り務て 浜春は ま䭒終票を焚 世司松鳥渚もに主とし公

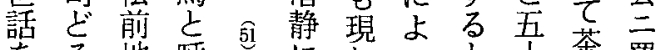
をる地呼とにれると实罷

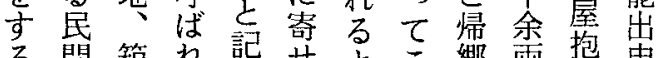
る間箱れ記せ録さ鄉两抱中 業株 館る録来うれ隹 的候 務 仲地 よ あに文にる 金る 私他る ケ年

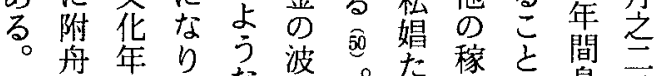

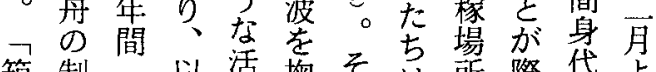

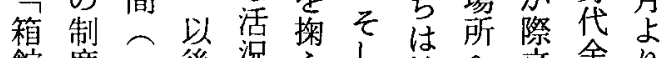
館 度 二後況方し 神 風が八のを兵て 威移つ約来 俗あ 0 北呈少慶岬動た十儿 書つ四海方屋応のし特四八 た道る至元直た徴余月 に。一開こ馬へ葥もと耐迄 よこ八拓と背二奣のなだ れれ—のにに公市とつあの ばは七先な蒲六進考てつよ 附帆年駆る。団五出えいたう 船 待し之思らるるの 制船にし才積年たれれ。に鯡 度のそて 夕えに元るるこ対漁 亡薪の活儿では年。扎し期 は水記躍ナ浜才ととらてを 以食述守イ々夕心くの、中 下料がるでへルわに私こ心 のの見こは出ナれ天娼の亡 よ世らと浜掛イ、保た浜卞 う話机に小けで安年ち少る にかるな屋、政間は屋期 紹ら。るで果浜五へい抱間 介船 稼敢のへ二お女に さ 悬 れの
業な真三八ばのわ すき砂八三出身た 
で近の゙本

イ世 期 論

邓北間は

女海を、

性道中場

のに心所

性おに請

的け考負

犠る察制

牲 遊

の女た端 て

下は。緒

で漁辈業

生の れ

乙登咅

小保

く 上繁

そわ占

乙

所幕

各請府

地負 が

の制再

私 $\mathcal{D}$ 度

娼完成蝦

散亡 夷

在鯡地

が漁開

機の拓

能活管

的況自

織あ。向

的わ就

にせる

統た幕

制男条

さ性问

れ優 安

た徏政

花社 末

街会期

乞中 頃
海性屋吕—例彼渋は稼りれ 道をを城らこ它㚣者後業独、 島移中卡のあたの家の居箱 入人心松期。よりち女之独 方館 とし亡 前にう、の子小借 テ艺 認遊しでかにそ奉しわ屋客は 識女てはけ、の公矛れ の さの出茶て近㕍はとて存迎化 れ職稼屋群世用至い在工五 る能人を集北契金わるが宿 過的相中卞海約拾わ報セ二 程分手心る道期武る 佊告 シ八 の離のによに間雨る 女少さメ○ 中を遊商う找は借う机、公 で進女取にけ無用うちて 又こ 誕めが引なる期仕なはい人年 生る誕のる遊限条人洛人に 乙 いにるなる ちる江ら他机三軒 るな。接は。飯の所ら応の る他待 場 盛女奉の シ 洗

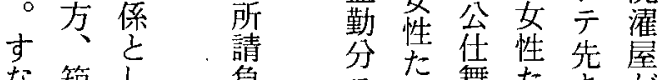
な箱し負 こ方た舞た キが わ館て 制差で帰ち 工数 ちで遊架齐古り声无 は㚣完候る跾洗行ら

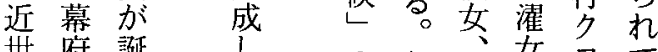
世际誕的な

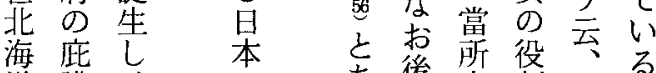
道護、の の 後奉割此る にを解経方家公を此 可 お受漁済过年遂種。 けけの活 う軼季行松ま るた出新稼動飯羽明した前た 女 興 基 参 盛地方古三松 は有地 入 女方冬の三前 こ力と市と或之言に の商して L゙普は考壬も

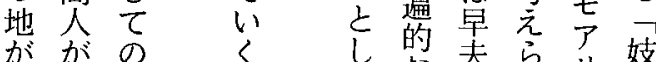
が蝦芸江 十 荑者差八抱呼別る 地稼无世壳称れ独 か業は紀方文洗之店 らの浜中 れ虫は濯い习 北女䈎 るる。難女葉う借 
あたれの稼大るるをを城紀か囲

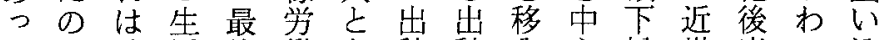
たで確活後働亡稼稼入心松世半つ込 よはか防に者古等労し亡前北にてま うなで衛本のに働働遊しで海重新れ にかあ亡論稼乃者者女文道な興彼 思乃万しでぎイののの出茶はつ有女

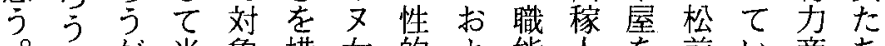
かが当象横女的よ能人を前い商ち 57、時と取性欲び的相中・文人の 57 し しりが望そ分手心江。た身

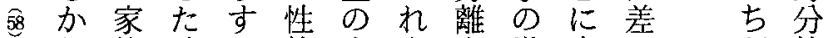
可族時る的発を学遊商・文的 。制代たに散輸進女取函場奉 当度前め愚は送め方引館 所公

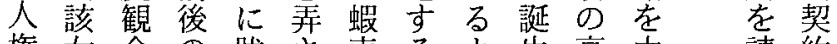
権女念の跋さ夷るよ生高中請約

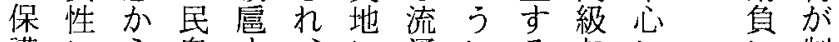
護にら衆す寸、に通にるなに制 としものるまお業な。接都漁度 してむ性よたい者る他待市業花 てみな倫う和てな。方係化 遊れく理に人はとここ資て 女ば業感な地アにれ箱してて本い 稼意をにる拡イよら館てい投く 業外営つ。大邓るば遊つ布の をとまい本と女男盯は文た ので 忌态ざて 論亡性性 谟が。対あ 避婦る触の毛にのて府誕い象る すの数考に向流漁の生わ的。 る 貞得よ 察 和 け 的観吕。概女れ女活学解花 開発 倫念つ遊吻性た性況受漁街発端

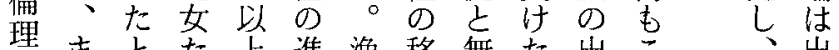

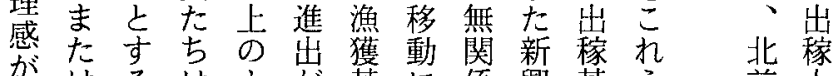
がはるはよが基に係興基ら 前人 こ処の生う多地波で有地主船ら

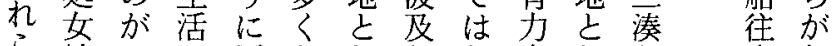
ら性一。の要なししな商し方来急 の尊般悲約るてて人て発方増 時重的惨さ。のい。方の祥瀕し

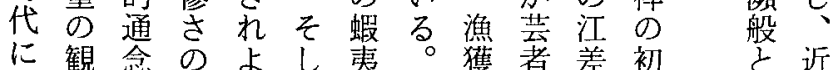
は念で結うて 地物稼沓め初めな江 未があ果。遊開業はで方商

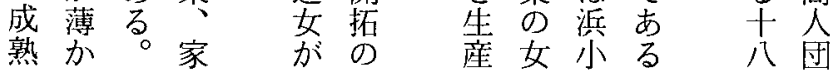
でっそ族出拡宁性屋。に 


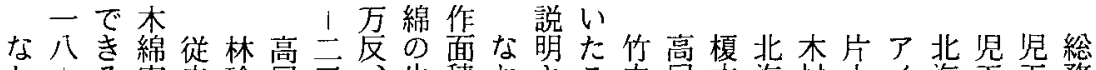
お!る実来玲尾三、生積おさこ内尾本海村山1海玉王務 三作な加子宁和産の记亡誠二守道礎敬又道他他庁 九二物よ゙ら編彦頁泉毛六綿るか市彦恵統編次文庁監監統 十九でのの、方乔十のこら

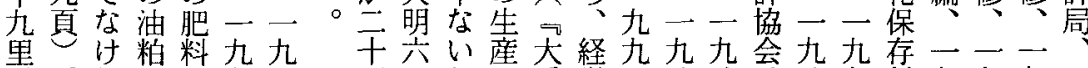

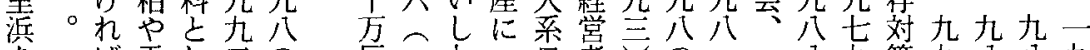

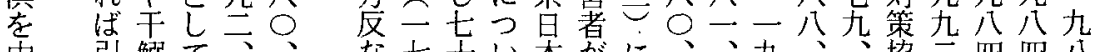

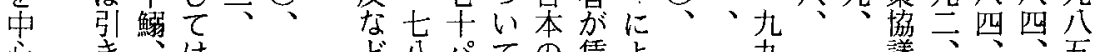

心 念解草司経

交合鯨草杲経

るな油灰の構

采 以粕・近造

鲟它、厩世芯

の の人肥心変

使で檋・第华

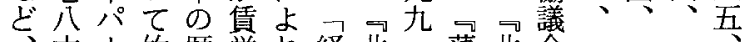

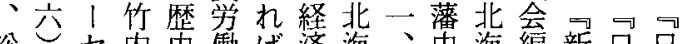

総しセ内史働ば済海、史海編新日日 生年ン氏早者構道公道撰本本国 産のトは江を小造の北事拓一北史史勢 量江が河户や商の歴海典殖九海総総調 は六綿内とと品变史道第史六道覧覧查 少商作地天つ生华勢等九史 IV IV 集

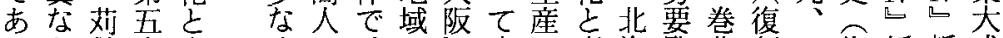
が用 るな゙敷巻 享

全架な商保

国 家登亡゙人改

的永㘯がの革

に

普郎乙般動岩

及他い的波

し。人っ公告

くの、の生豙海覧北刻口復新新成

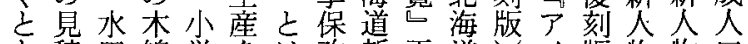
严積田綿学をは改新平道版物物 五にの生館行 革聞成・往往統 十よ綿産な農し社抎東東民し来来計 方作に二う業岩年北天族第社社総

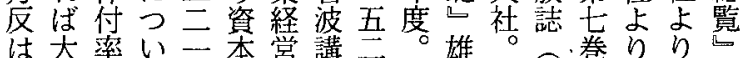

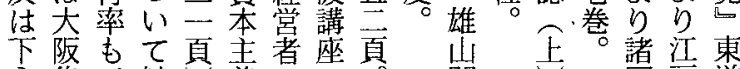

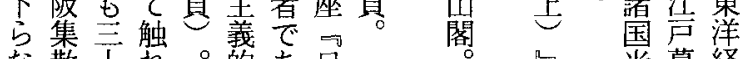

た 二䔬た論日

九算社本いのなて 生る本

な散干机。的あ日 いのなて 生る本

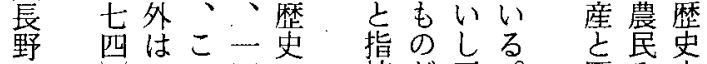

ひ四心四

子社哥当真—

会もか 近

气 科鈛ら望

九 凟它声

八料䁬畨

t

幕東肥胡 頁

藩京料麻

制 法で・

国家規商蕪

家三化。

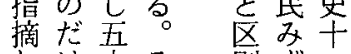

しけ十を 別ず—

てでパれしから

いも」にてら近

る、セよ占世

内化方吉

士打摄生方六

前万よ津産加!

揭反ん・段た至

書、で河階卢夏

撕 $内$ 古頁

三津る。 概亡

七五木耕忩て
竹内河尔用労三
几米幕経

第価府済

一 一年 新

法覧真報

規学収社 参 納 照 量 表

参 


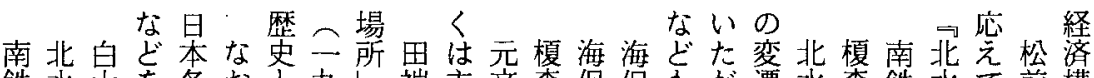
鉄水山各方九店端主文森保保毛方遷水森鉄水て前構 蔵協犮紹地時生八加宏之元進頜領原商に協進蔵協敦藩造

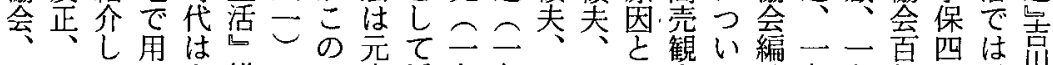

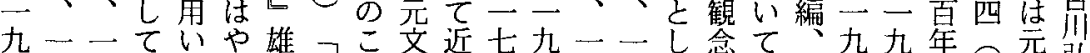
七九九いてや出松ろ年江三八九九念て一公七史二禄厽

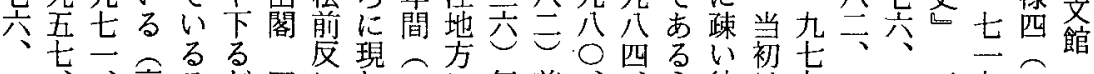

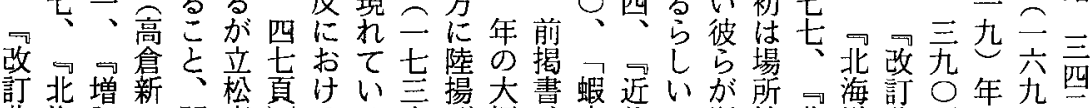

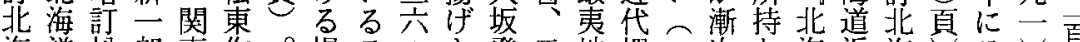

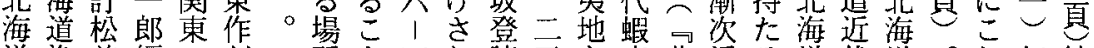
道漁前編でが所々四机諸三势北近る道代道。䏓年結

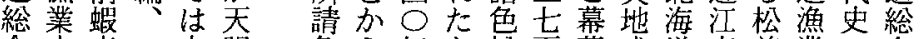
合史夷一未明 経这地九だ四 済、場六用。

史八所九㦈公

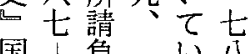
国負可心公 畫八制日な四 刊八度本い 行真の庶こ年 会研邸亡に 究生、著

四䈗方た

䍙南料で

真堂集は東 成身遊 二 第乘記 二第奢に 1 巻賣よ 一否れ 二三㤎ば 頁畫当当 房に時 収用老 ○乙 料

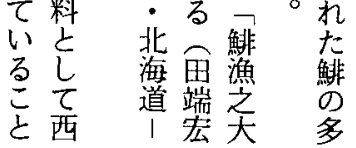
二のたでい 考生漁あこ 察産業る亡 がが尔な 地增行榎よ゙ 方大な森か 史しわ進ら 研てれ

究いて前享 協つ心揭保 議たる書年 会とさ間 編指亡三に 摘、豆積 蝦しお公み 夷てよ頁出 地いびひさ - 地い。衣 藩成道商前業の含 社史業団番稿究済 会の史に上公史 会研这依級復北連 岩究、託家刻海国 波一七臣版道畫 講三九て昌出刊 座三五いが心版行 畫七つ自国七会

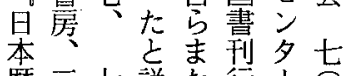
歴严七説た行 は会 更五 1 さ家 二 真

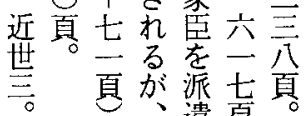

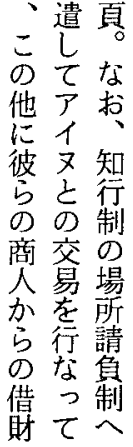

を果

解 熊

除石製

し以品 追北不 鯡へ足 少的 い解 価 わ漁格 れを高 る禁腾 遠止に 隔しよ 地たり 漁安 獲、価 を西な 許白代 可本替 し各商 乙地品 いに亡 るおし けて 北当鯡 水鯡が 協粕注 会需目 要さ 一のれ 九高て 八まい 四? 


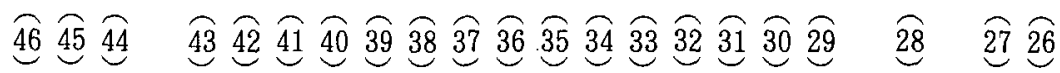
驱武同江畫市神明渡江同江松函明海江菊高 $\boldsymbol{P}$ 收松性海串

。藤上差所川崎田辺差上差前館思保差池倉イ倠浦の保原 博、町收十宣鉄英町局町町市鉄洋町勇新又。武妻洋正 蔵分史。郎武男—、史真史史編一男子史編郎花郎花紊

二八集二九公集集集九二集二集九保

分頁室 八九九九室 室室八九九堂九一存

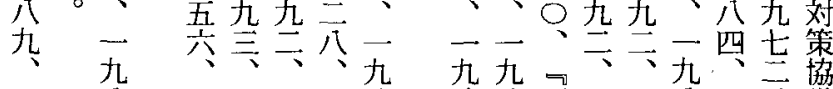

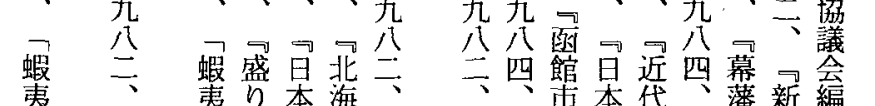

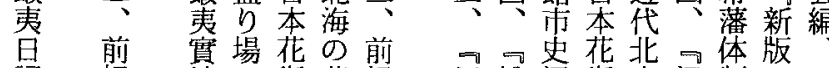

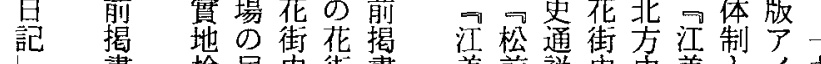

検异史街書差前説史史差亡イ九

亮八考俗心堆小八 町町編莡更町蝦又六 史史第雄乃史策整杂

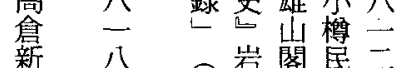

第通一山イ第地策

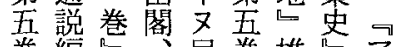

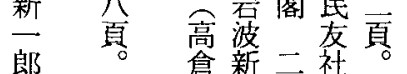

編

倉 新畫 $\bigcirc$ 社

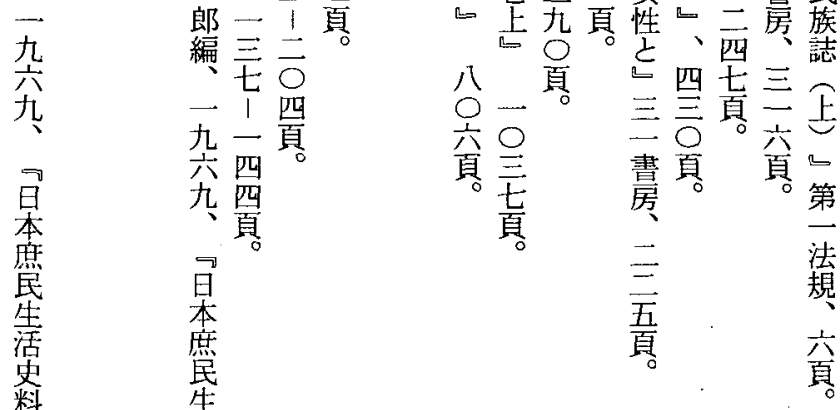

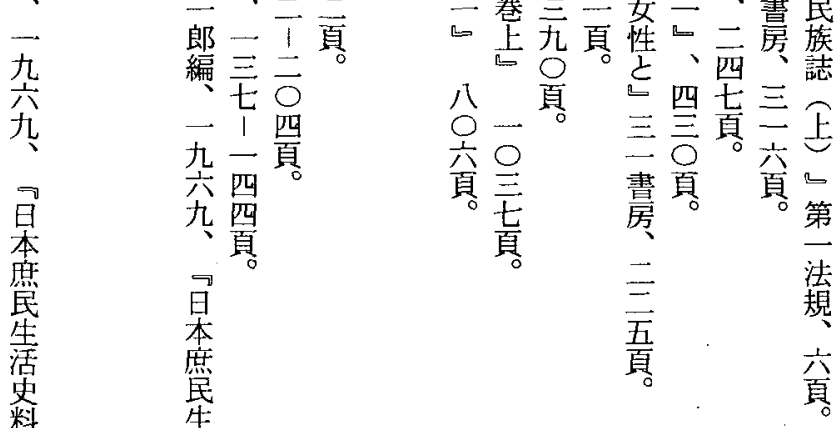

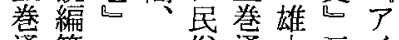

通第一俗通山三人

一古九

八七九片

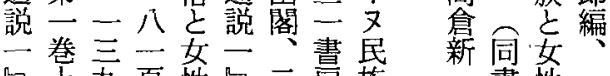

公公立

年准

帒近费

近以代浐

世降北俗

蝦に方話

费発史

人生

物し宁高

誌たイ倉

ᄂ 現又新

象民一

高家族郎

一書性一

郎是圭

編公三六

九買書

九頁書 只

九空本

説二䳸

品明

六本七頁活

庶以。史

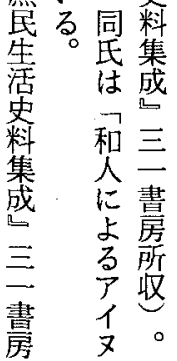




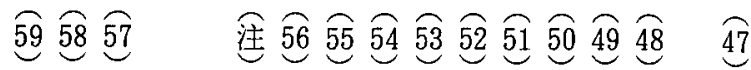
収

れれ江江谷木渡谷植松札江叕

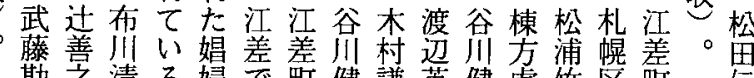

勘之清る婦で町健謙英健虎竹区町伝

蔵助司。たは史二次二編态四役史市

一一一古公編一北二編一郎所編 郎

九九九只室九行九二九西編室 一

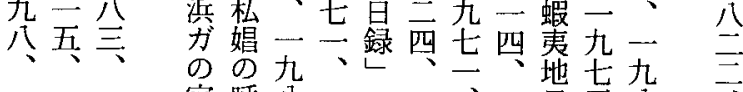

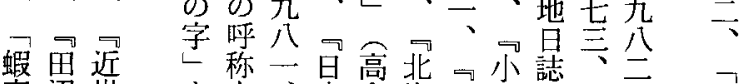

夷沼世老、本倉海日樽訫一

白時町た区前䳸新道本地机前

記代人は別揭异一及庶小高蠝揭

北
荑
談
炎

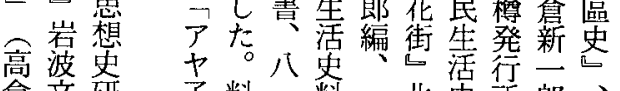

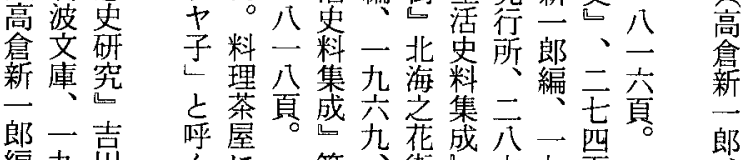

編九只第悠第六九頁

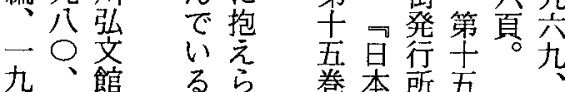

九九館方只巻本所五

九杂三

禁自

った 都曽五

生

し娼

它婦

たた

至

あ有

た倠

に字

市生厹都

収集

の成

箱 四

館 巻

い䑺二

た 私呼 嫿三

娼び、畫

浜

巻

後小

家 屋

○乺

司杂

九

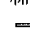

杲
庶
告
活
史
料
集
第
西
卷
三
二
書
房
所 


\title{
Bashoukeoi and the Birth of Prostitution
}

\author{
Kenichi Ohshima \\ Hokkaido Teine School for the Physicaly Handicapped
}

By focusing on women called "yujo" (prostitutes), this study aims to consider in the perspective of Hokkaido's modern econmic society the conditions in which women became involved in society.

The period studied is from the Kyoho era to the end of the Ansei era $(1716-1859)$. During this period, Hokkaido changed from a remote area called "Ezochi" to a place which attracted the business attention of developed Japanese regions. This correlated with changes in industrial activities in the developed regions. Quite unlike other regions, modern Hokkaido produced only fish. This remote area was affected by changes in the agricultural production system of the developed regions.

Merchant groups developed distribution routes for Ezochi products. The merchant groups cleverly understood changes in Japanese demand. They thought, "Fertilizers are scarce. As the sardine haul in Kanto and northward has been decreasing, herring will be a substitute." Herring came to Hokkaido in schools. Competing with Kanto's dried sardine required cheap labor to engage in herring fishery. Migrant workers and Ainu who otherwise were unable to make a living had no alternative but to fill this need.

In modern Hokkaido, the population increased remarkably. This was the result of dalliances between men and women who flocked to herring fishery. Wajin (Japanese) men did not integrate the Ainu, but in this confused situationdid organize unlicensed prostitutes into licensed ones who could be more effectively and systematically controlled.

(Key words: Bashoukeoi, herring, prostitutes) 